\title{
Assessment of Constraints Faced by Dairy Farmers and Livestock Development Officers in Managing Reproductive Disorders in Parbhani District of Maharashtra, India
}

\author{
Akash Maske*, Amol Patil, Dhananjay Deshmukh, \\ Babulal Kumawat and Manojkumar Pande
}

College of Veterinary and Animal Sciences, Parbhani (MS) - 431402, India

*Corresponding author

\section{A B S T R A C T}

\section{Keywords}

Constraints, Dairy farmers, Livestock development officers and Reproductive disorders

\section{Article Info}

Accepted:

14 June 2020

Available Online:

10 July 2020

\begin{abstract}
A research survey was conducted during March to May 2019, assessing the constraints that are regularly faced by 200 dairy farmers while managing the reproductive disorders. The same research was conducted on 20 Livestock Development Officers (Veterinary Officers) while treating the cases of reproductive disorders in Parbhani district of Maharashtra state. It was found that unavailability of veterinary hospitals in nearby areas, high cost of concentrates and late maturity shown by non-descript local breeds available to farmers were the most relevant technical, financial \& economic constraints faced by dairy farmers, respectively while inadequacy of high cost instruments and diagnostic tools were the most prevalent constraints before the Livestock Development Officers.
\end{abstract}

\section{Introduction}

Dairy farming is considered as an important mean that can alleviate the poverty and also has remained one of the most important components in the traditional farming system of the country (Yankam, 2016). However, the business in India stands as the best example of production by masses rather than mass production (Srivastava, 2015).

Milk production and productivity were, both, enhanced by various means including ensuring the introduction of improved and balanced feed, availability of veterinary services, artificial insemination (AI) and farmers' education regarding clean milk production and reproductive disorders (Meeta Punjabi, 2009).

Reproductive health may be considered as the back-bone of dairy industry; but some reproductive disorders have been found to be major reasons for decreased reproductive 
efficiency of dairy animals (Abdisa, 2018). Reproductive disorders in dairy animals like anoestrus, repeat breeding, dystocia, retention of placenta and prolapse affect profitability of the herd by lowering milk production (short term drop) and total number of calves produced, by increasing expenditure in term of veterinary service charge and medicine cost, increased culling rate and increasing inter-calving period. Profitability of the dairy herd, good heat detection and conception rate are influenced by an important factor i.e. reproductive performance (Grohn and Rajala - Schultz, 2000).

Constraints can be implied here to quote the problems or hindrance faced by dairy farmers while adopting day-to-day animal husbandry practices in their dairy enterprises. If these constraints are identified, they are helpful to bridge the gap between dairy technology and its adoption by dairy farmers (Rathod et al., 2014). The present study was conducted to identify the constraints faced by dairy farmers and Livestock Development Officers while managing the reproductive disorders at farm or at Veterinary Dispensary.

\section{Materials and Methods}

The current study was conducted in four Talukas (viz. Manwat, Parbhani, Purna and Jintur) to record responses from farmers by personal interview method. Two hundred (200) dairy farmers with minimum three dairy animals and minimum of three years of experience in dairy business, were selected as respondents. The responses of twenty (20) Livestock Development Officers (LDO/ VO) were recorded from all over the district. Thirteen most frequently faced constraints were asked to dairy farmers and fifteen most frequently faced constraints by LDOs selected by pre - testing the data on the basis of pilot studies and prior discussion with subject experts. A three-point (3) frequency continuum was used to record the responses e.g. 3 for 'most relevant', 2 for 'relevant' and 1 for 'non relevant' options. The recorded responses were then analyzed by using frequency and percentage. The constraints were ranked according to the frequency recorded.

\section{Results and Discussion}

The data recorded while interviewing dairy respondents was categorized into three categories i.e. Technical constraints, Economic constraints and Situational constraints while, responses recorded by LDOs were listed according to frequency.

The present study revealed following results:

\section{Technical constraints}

Most of the dairy respondents (51.5\%) farmers have reported unavailability of veterinary hospitals in nearby is the most relevant technical constraint. Unavailability of A. I. services $(22 \%)$ was ranked $2^{\text {nd }}$ technical constraint. Similarly, unavailability of veterinarians in emergency (12.5\%), poor knowledge of farmers regarding signs and symptoms of reproductive disorders (5.5\%), lack of farmers' knowledge regarding identification of heat signs in cattle or buffaloes (2\%).

The pre-quoted technical constraints were ranked in respective order as $3^{\text {rd }}, 4^{\text {th }}$ and $5^{\text {th }}$. It was an encouraging thing to note that majority $(95.5 \%)$ dairy farmers never took their dairy animals to village quacks for the treatment on reproductive disorders hence it was ranked as the last $\left(6^{\text {th }}\right)$ in the constraint list. Observations are in conformity with results found with researcher Sharma et al., (2010). 
Table.1 Constraints faced by dairy farmers to manage reproductive disorders

\begin{tabular}{|c|c|c|c|c|c|c|}
\hline Sr. No. & Constraints & $\begin{array}{c}\text { Most } \\
\text { relevant }\end{array}$ & $\begin{array}{c}\text { Less } \\
\text { relevant }\end{array}$ & $\begin{array}{c}\text { Non } \\
\text { relevant }\end{array}$ & Total & Rank \\
\hline \multicolumn{7}{|c|}{ A. Technical constraints } \\
\hline 01 & $\begin{array}{l}\text { Unavailability of } \\
\text { veterinary hospitals } \\
\text { nearby }\end{array}$ & $\begin{array}{c}103 \\
(51.5 \%)\end{array}$ & $\begin{array}{c}52 \\
(26.0 \%)\end{array}$ & $\begin{array}{c}45 \\
(22.5 \%)\end{array}$ & $\begin{array}{c}200 \\
(100.0)\end{array}$ & I \\
\hline 02 & $\begin{array}{l}\text { Unavailability of A.I. } \\
\text { services }\end{array}$ & $\begin{array}{c}44 \\
(22.0 \%)\end{array}$ & $\begin{array}{c}101 \\
(50.5 \%)\end{array}$ & $\begin{array}{c}55 \\
(27.5 \%)\end{array}$ & $\begin{array}{c}200 \\
(100.0)\end{array}$ & II \\
\hline $\mathbf{0 3}$ & $\begin{array}{l}\text { Unavailability of } \\
\text { veterinarians in } \\
\text { emergency }\end{array}$ & $\begin{array}{c}25 \\
(12.5 \%)\end{array}$ & $\begin{array}{c}129 \\
(64.5 \%)\end{array}$ & $\begin{array}{c}46 \\
(23.0 \%)\end{array}$ & $\begin{array}{c}200 \\
(100.0)\end{array}$ & III \\
\hline 04 & $\begin{array}{l}\text { Poor knowledge } \\
\text { regarding signs and } \\
\text { symptoms of } \\
\text { reproductive disorders }\end{array}$ & $\begin{array}{c}11 \\
(5.5 \%)\end{array}$ & $\begin{array}{c}63 \\
(31.5 \%)\end{array}$ & $\begin{array}{c}126 \\
(63.0 \%)\end{array}$ & $\begin{array}{c}200 \\
(100.0)\end{array}$ & IV \\
\hline 05 & $\begin{array}{l}\text { Lack of knowledge } \\
\text { regarding identification } \\
\text { of heat signs }\end{array}$ & $\begin{array}{c}04 \\
(2.0 \%)\end{array}$ & $\begin{array}{c}105 \\
(52.5 \%)\end{array}$ & $\begin{array}{c}91 \\
(45.5 \%)\end{array}$ & $\begin{array}{c}200 \\
(100.0)\end{array}$ & $\mathbf{V}$ \\
\hline 06 & $\begin{array}{l}\text { Treatment by village } \\
\text { quacks }\end{array}$ & $\begin{array}{c}0 \\
(0.0 \%)\end{array}$ & $\begin{array}{c}09 \\
(4.5 \%)\end{array}$ & $\begin{array}{c}191 \\
(95.5 \%)\end{array}$ & $\begin{array}{c}200 \\
(100.0)\end{array}$ & VI \\
\hline \multicolumn{7}{|c|}{ B. Financial constraints } \\
\hline 07 & $\begin{array}{l}\text { High cost of } \\
\text { concentrates/ feed }\end{array}$ & $\begin{array}{c}149 \\
(74.5 \%)\end{array}$ & $\begin{array}{c}48 \\
(24.0)\end{array}$ & $\begin{array}{c}03 \\
(1.5 \%)\end{array}$ & $\begin{array}{c}200 \\
(100.0)\end{array}$ & I \\
\hline 08 & High treatment costs & $\begin{array}{c}144 \\
(72.0 \%)\end{array}$ & $\begin{array}{c}49 \\
(24.5 \%)\end{array}$ & $\begin{array}{c}07 \\
(3.5 \%)\end{array}$ & $\begin{array}{c}200 \\
(100.0)\end{array}$ & II \\
\hline 09 & $\begin{array}{l}\text { High cost of medicines } \\
\text { and vaccines }\end{array}$ & $\begin{array}{c}107 \\
(53.5 \%)\end{array}$ & $\begin{array}{c}84 \\
(42.0 \%)\end{array}$ & $\begin{array}{c}90 \\
(4.5 \%)\end{array}$ & $\begin{array}{c}200 \\
(100.0)\end{array}$ & III \\
\hline \multicolumn{7}{|c|}{ C. Situational constraints } \\
\hline 10 & $\begin{array}{l}\text { Late maturity shown by } \\
\text { non - descript local } \\
\text { breeds }\end{array}$ & $\begin{array}{c}124 \\
(62.0 \%)\end{array}$ & $\begin{array}{c}67 \\
(33.5 \%)\end{array}$ & $\begin{array}{c}09 \\
(4.5 \%)\end{array}$ & $\begin{array}{c}200 \\
(100.0)\end{array}$ & I \\
\hline 11 & Shortage of green fodder & $\begin{array}{c}60 \\
(30 \%)\end{array}$ & $\begin{array}{c}92 \\
(46 \%)\end{array}$ & $\begin{array}{c}48 \\
(24 \%)\end{array}$ & $\begin{array}{c}200 \\
(100.0)\end{array}$ & II \\
\hline 12 & $\begin{array}{l}\text { Lack of emergency } \\
\text { veterinary services }\end{array}$ & $\begin{array}{c}40 \\
(20.0 \%)\end{array}$ & $\begin{array}{c}145 \\
(72.5 \%)\end{array}$ & $\begin{array}{c}15 \\
(7.5 \%)\end{array}$ & $\begin{array}{c}200 \\
(100.0)\end{array}$ & III \\
\hline 13 & $\begin{array}{l}\text { Lack of communication } \\
\text { facilities in remote areas }\end{array}$ & $\begin{array}{c}34 \\
(17 \%)\end{array}$ & $\begin{array}{c}144 \\
(72 \%)\end{array}$ & $\begin{array}{c}22 \\
(11 \%)\end{array}$ & $\begin{array}{c}200 \\
(100.0)\end{array}$ & IV \\
\hline
\end{tabular}


Table. 2 Constraints faced by Veterinary Officers to manage reproductive disorders

\begin{tabular}{|c|c|c|c|c|c|}
\hline $\begin{array}{l}\text { Sr. } \\
\text { no. }\end{array}$ & Constraint & $\begin{array}{c}\text { Most } \\
\text { relevant }\end{array}$ & $\begin{array}{l}\text { Less } \\
\text { relevant }\end{array}$ & $\begin{array}{l}\text { Non } \\
\text { relevant }\end{array}$ & Rank \\
\hline 1 & $\begin{array}{l}\text { Inadequacy of high cost, advanced } \\
\text { diagnostic tools }\end{array}$ & $\begin{array}{c}14 \\
(70 \%)\end{array}$ & $\begin{array}{c}06 \\
(30 \%)\end{array}$ & $\begin{array}{c}00 \\
(0 \%)\end{array}$ & I \\
\hline 2 & $\begin{array}{l}\text { Ignorance of farmers towards } \\
\text { reproductive disorders }\end{array}$ & $\begin{array}{c}14 \\
(70 \%)\end{array}$ & $\begin{array}{c}05 \\
(25 \%)\end{array}$ & $\begin{array}{c}01 \\
(05 \%)\end{array}$ & II \\
\hline 3 & Inadequate staff & $\begin{array}{c}13 \\
(65 \%)\end{array}$ & $\begin{array}{c}07 \\
(35 \%)\end{array}$ & $\begin{array}{c}00 \\
(00 \%)\end{array}$ & III \\
\hline 4 & Large area covered under a single clinic & $\begin{array}{c}12 \\
(60 \%)\end{array}$ & $\begin{array}{c}07 \\
(35 \%)\end{array}$ & $\begin{array}{c}01 \\
(05 \%)\end{array}$ & IV \\
\hline 5 & Farmers cannot afford cost of treatment & $\begin{array}{c}11 \\
(55 \%)\end{array}$ & $\begin{array}{c}07 \\
(35 \%)\end{array}$ & $\begin{array}{c}02 \\
(10 \%)\end{array}$ & $\mathbf{V}$ \\
\hline 6 & Lack of infrastructure & $\begin{array}{c}10 \\
(50 \%)\end{array}$ & $\begin{array}{c}07 \\
(35 \%)\end{array}$ & $\begin{array}{c}03 \\
(15 \%)\end{array}$ & VI \\
\hline 7 & $\begin{array}{l}\text { Use of bull or semen of bull affected by } \\
\text { reproductive disorders }\end{array}$ & $\begin{array}{c}10 \\
(50 \%)\end{array}$ & $\begin{array}{c}05 \\
(25 \%)\end{array}$ & $\begin{array}{c}05 \\
(25 \%)\end{array}$ & VII \\
\hline 8 & $\begin{array}{l}\text { Farmers delay to bring animal to } \\
\text { veterinary clinic }\end{array}$ & $\begin{array}{c}09 \\
(45 \%)\end{array}$ & $\begin{array}{c}10 \\
(50 \%)\end{array}$ & $\begin{array}{c}01 \\
(05 \%)\end{array}$ & VIII \\
\hline 9 & $\begin{array}{l}\text { Housing and quarter facilities are } \\
\text { improper }\end{array}$ & $\begin{array}{c}09 \\
(45 \%)\end{array}$ & $\begin{array}{c}07 \\
(35 \%)\end{array}$ & $\begin{array}{c}04 \\
(20 \%)\end{array}$ & IX \\
\hline 10 & Lack of follow up after treatment & $\begin{array}{c}08 \\
(40 \%)\end{array}$ & $\begin{array}{c}12 \\
(60 \%)\end{array}$ & $\begin{array}{c}00 \\
(0 \%)\end{array}$ & $\mathbf{X}$ \\
\hline 11 & Farmers prefer livestock supervisors & $\begin{array}{c}08 \\
(40 \%)\end{array}$ & $\begin{array}{c}10 \\
(50 \%)\end{array}$ & $\begin{array}{c}02 \\
(10 \%)\end{array}$ & $\mathbf{X I}$ \\
\hline 12 & Inadequate drug and vaccine supply & $\begin{array}{c}08 \\
(40 \%)\end{array}$ & $\begin{array}{c}09 \\
(45 \%)\end{array}$ & $\begin{array}{c}03 \\
(15 \%)\end{array}$ & XII \\
\hline 13 & $\begin{array}{l}\text { Farmers never provide complete true } \\
\text { information }\end{array}$ & $\begin{array}{c}07 \\
(35 \%)\end{array}$ & $\begin{array}{c}10 \\
(50 \%)\end{array}$ & $\begin{array}{c}03 \\
(15 \%)\end{array}$ & XIII \\
\hline 14 & Lack of additional incentives & $\begin{array}{c}07 \\
(35 \%)\end{array}$ & $\begin{array}{c}08 \\
(40 \%)\end{array}$ & $\begin{array}{c}05 \\
(25 \%)\end{array}$ & XIV \\
\hline 15 & $\begin{array}{l}\text { Poor feeding and management to the } \\
\text { animals }\end{array}$ & $\begin{array}{c}04 \\
(20 \%)\end{array}$ & $\begin{array}{c}14 \\
(70 \%)\end{array}$ & $\begin{array}{c}02 \\
(10 \%)\end{array}$ & $\mathbf{X V}$ \\
\hline
\end{tabular}

\section{Financial constraints}

Study on financial constraints revealed that high cost of concentrates/ feed was the most relevant financial constraint faced by about $2 / 3^{\text {rd }}$ dairy farmers hence it was ranked as the $1^{\text {st }}$ in the list of financial constraints. High treatment costs and high cost of medicines and vaccines were ranked as $2^{\text {nd }}$ and $3^{\text {rd }}$ most relevant financial constraint. There may be some of the reasons like lower annual/ monthly income that they are facing this constraint. These findings were in association with Patel et al., (2013).

\section{Situational constraints}

Considering the situational constraints, late maturity shown by non-descript local breeds available to farmers was recorded as the most 
relevant situational constraint faced by most of the dairy farmers $(62 \%)$. Shortage of green fodder $(30 \%)$, lack of emergency veterinary services $(20 \%)$ and lack of communication facilities in remote areas (17\%) were ranked as $2^{\text {nd }}, 3^{\text {rd }}$ and $4^{\text {th }}$ situational constraints according to their relevance.

These findings were in contrast with Chand (2011) and Rajput et al., (2018).

\section{Constraints faced by livestock development officer}

The observations mentioned below clearly indicate that the constraints regarding inadequacies of various diagnostic tools was the most relevant one faced by LDOs. This was followed by ignorance of farmers towards reproductive disorders, inadequate staff, large jurisdictional area covered under a single clinic, farmers could not afford the cost of treatment, lack of infrastructure, use of semen of bull affected by reproductive disorders, delay in bringing animals to veterinary clinic by farmers, improper housing and quarter facilities to incumbent officers. lack of follow up after treatment of reproductive disorders, preference of farmers to Livestock Supervisors over LDOs/ VOs, inadequate drug and vaccine supply, farmers never provide true information, lack of additional incentives and poor feeding and management practices by farmer were put according to the relevance. Singh (2001) revealed the similar findings in his study and hence in line with him.

In conclusion, Indian dairy industry stands at the top of the list of the leading dairy industry players; but problems like reproductive disorders causes more economic losses than anything else. Knowing the constraints and trying to improve them will definitely help to minimize the intensity of constraints. Establishing new veterinary dispensaries, allocating latest diagnostic tools, producing cost effective concentrates may help both farmers and LDOs to overcome these constraints.

\section{References}

Abdisa, Tagesu, 2018. Review on reproductive health problem of dairy cattle, Journal of dairy and veterinary science, 5(1).

Chand, S., 2011. Analysis of reproductive disorders in dairy animals of Alwar district of Rajasthan. M.V.Sc. thesis. National Dairy Research Institute (Deemed University), Karnal, Haryana, India.

Grohn, YT and Kajala - Schultz PJ, 2000. Epidemiology of reproductive performance of dairy cows, Animal reproduction science, $60-61,605-$ 614. Abstract only.

Meeta, Punjabi, Increasing Demand Challenges of the Dairy Sector, Food and Agricultural organisation [online], Available from http://www.fao.org/3/i0588e/I0588E05. htm.

Patel N. B., L. H. Sayyad, T. K. S. Rao, Rana Ranjit singh, R. J. Modi \& G. P. Sabapara, 2013. Status and constraints of dairying in the tribal households of Narmada valley of Gujarat-India, Animal Science Report, 7, (3): 83 - 89.

Rajput, J. S., K. S. Kirad, A. K. Badaya and S. S. Chauhan, 2018. Constraints faced by dairy farmers while adopting animal management practices in Dhar district of Madhya Pradesh, India. International Journal of Current Microbiological and Applied Sciences, 7, (1): 3163 - 3166.

Sharma, K., S. P. Singh, Gautam, 2010. Constraints perceived by dairy farmers in adoption of recommended buffalo husbandry practices. Indian Journal of Dairy Science, 63, (3): 225 - 232. 
Singh, O., 2001. Perception of farmers and veterinary officers towards infertility in dairy animals. M.Sc. thesis, National Dairy Research Institute, Karnal, Haryana, India.
Srivastava, A.K., Kumaresan, A., 2015. Indian Dairy Industry - The Changing and Prospective Scenario. Intas polivet, 16, (1): $1-10$. Abstract only.

\section{How to cite this article:}

Akash Maske, Amol Patil, Dhananjay Deshmukh, Babulal Kumawat and Manojkumar Pande. 2020. Assessment of Constraints Faced by Dairy Farmers and Livestock Development Officers in Managing Reproductive Disorders in Parbhani District of Maharashtra, India. Int.J.Curr.Microbiol.App.Sci. 9(07): 1319-1324. doi: https://doi.org/10.20546/ijcmas.2020.907.152 